\title{
The Development of Sociocultural Component in Professional Education of Future Navigators in the Fifties of the XXth Century
}

\author{
Penza Iryna \\ ORCID https://orcid.org/0000-0002-8984-188X \\ Postgraduate student \\ Municipal higher education institution "Kherson Academy of Continuing \\ Education" of Kherson Regional Council (city Kherson, Ukraine)
}

\begin{abstract}
The article is devoted to developing the socio-cultural component in professional education of future navigators in the 50s of the XXth century. Considered resolutions of the Central Committee of the CPSU (b) and the Central Committee of the CPSU, which influenced the teaching of disciplines that represent the socio-cultural component. Determined that during this period the leadership of party bodies was strengthened by scientific institutions of the republic, topics of friendship with people, Soviet patriotism, history of development of sociopolitical, philosophical and economic thought in Ukraine were obligatory for studying in higher and secondary special educational institutions. Described Russian socio-political thought and culture for the development of Ukrainian culture. It is concluded that since the educational institutions for training future navigators were subject to the regulations of the education sphere, and the development of the socio-cultural component of education is characterized by excessive politicization and ideology.

Key words: development, socio-cultural component of education, future navigators, social disciplines, resolution, educational institutions.

Актуальність дослідження. Питання розвитку соціокультурної складової професійної освіти майбутніх судноводіїв $€$ надзвичайно актуальним у зв'язку 3 інтеграцією України до Свропейського союзу та необхідністю вивчення, освоєння та використання світових водних ресурсів. Історико-педагогічні пошуки дозволяють розкрити характер еволюції знань про досліджувану проблему, простежити модифікації з досліджуваного питання та визначити його вплив на сучасний стан педагогічної науки.

Попередні статті ми присвятили визначенню поняття «соціокультурної складової освіти майбутніх судноводіїв», студіюванню категорійно-понятійного апарату проблеми розвитку соціокультурної складової професійної освіти майбутніх судноводіїв, кореляції понять «соціокультурна складова освіти» та «соціокультурна компетентність» $[1 ; 6 ; 14]$. Таким чином було визначено, що «соціокультурна складова професійної освіти майбутніх судноводіїв» - це змістовна компонента їх професійної освіти, що поєднує знання, вміння та навички, які допомагають ефективно здійснювати професійну діяльність з урахуванням суспільних, мисленнєвих, соціальних, культурних,
\end{abstract}


ціннісних факторів та вести ефективну діяльність у полікультурному середовищі, що включає знання обов'язків із несення вахти на містку, з радіослужби, обов'язків представника командного складу багатомовного екіпажу тощо. А «розвиток соціокультурної складової професійної освіти майбутніх судноводіїв» як частина змісту освіти судноводіїв - це процес, у результаті якого відбуваються якісні зміни, зростає ступінь освіченості, культурності, здібностей та потенціалу, професійної компетентності представників палубної команди, передбаченої Міжнародною конвенцією про підготовку і дипломування моряків та несення вахти $[1 ; 6 ; 14]$.

Значна кількість вітчизняних вчених наголошує на актуальності соціокультурної складової освіти, серед них Л. Вольнова, О. Касаткіна, А. Клебанська, О. Коломинова, М. Максимець, А. Мурзіна, Л. Петько [8; 9; 18]. Дане питання у сфері морської освіти висвітлено у працях М. Бабишеної, Н. Бобришевої, С. Козак, Л. Ліпшиць, Н. Слюсаренко [14; 15; 16; 19], О. Фролової та ін. Своєю чергою, Л. Ліпшиць та Н. Слюсаренко зазначають, що соціокультурна компетентність дозволяє курсантам усвідомлювати різницю між культурами, долати соціокультурні відмінності [14, с. 39], а формування соціокультурної компетентності відбувається у процесі вивчення дисциплін соціально-гуманітарного циклу [16, с. 21].

Проте аналіз історико-педагогічних робіт свідчить, що не існує комплексного вичерпного дослідження розвитку соціокультурної складової професійної освіти майбутніх судноводіїв у 50-70-ті pр. ХХ століття, тому дане дослідження є актуальним, а його результати можуть бути використані для характеристики розвитку морської освіти у визначений хронологічний відрізок та для вдосконалення підготовки судноводіїв сьогодні.

Виклад основного матеріалу. У 50-ті рр. ХХ ст. на землях, не так давно визволених від фашистських загарбників, почалась робота з відновлення зруйнованого господарства. Значна увага приділялась діяльності морського транспорту та перспективам подальшого розвитку флоту. Основними характеристиками освіти даного періоду є доступність для всіх верств населення, політехнізація, зв'язок з політикою, спрямованість на формування людини з глибокими комуністичними переконаннями.

Науки суспільно-гуманітарного циклу (політична економія, діалектичний та історичний матеріалізм, історія СРСР/КПРС, філософія, мови, література) 
репрезентують соціокультурну складову освіти. У досліджуваний відтинок часу вимоги до їхнього викладання змінювались у результаті прийняття нормативно-правових актів, серед яких: Постанова ЦК ВКП (б) від 06.08.1951 р. «Про заходи щодо покращення викладання суспільних наук у вищих навчальних закладах» [3, с. 245-249] та Постанова ЦК КПРС від 18.06.1956 р. «Про викладання у вищих навчальних закладах політичної економії, діалектичного та історичного матеріалізму та історії КПРС» [7, с. 96].

У Постанові ЦК ВКП (б) від 06. 08. 1951 р. «Про заходи щодо покращення викладання суспільних наук у вищих навчальних закладах» зосереджувалась увага на необхідності виховання у студентів усвідомленого та творчого відношення до вивчення теорії, зв'язку викладання суспільних наук з практикою, залученні значного матеріалу 3 області політичного, господарського, культурного життя під час їх вивчення. Згідно 3 даною постановою розширювалась підготовка викладачів суспільних дисциплін, 3 1951 р. збільшувався набір до аспірантури вузів з марксизму-ленінізму - 250 чоловік, політекономії - 50, філософії - 50 [3, с. 245-249].

На пленумах ЦК КП/б/У наголошувалось на необхідності посилити керівництво партійних органів науковими закладами республіки, спрямувати їхню увагу на розробку проблем, пов'язаних із завданнями комуністичного будівництва. Особлива увага приділялась посиленню роботи інститутів суспільних наук, підвищенню кваліфікації наукових співробітників, їх вихованню у дусі непримиренності до недоліків, приятелізму, безпринципності. Партія ставила завдання перед науковими кадрами створити праці, які б висвітлювали питання дружби народів, радянського патріотизму, історії розвитку суспільно-політичної, філософської та економічної думки в Україні, корисного впливу російської суспільно-політичної думки та культури на розвиток української культури, історичної дружби українського та російського народів $[11$, c. 34-35].

Робота $з$ архівними джерелами дає підстави констатувати високі вимоги й до викладачів середніх спеціальних морських закладів. У річних звітах Херсонського морехідного училища Міністерства морського флоту часто надавалась характеристика окремих викладачів, взаємовідвідування занять відбувалось не лише з метою обміну методичними прийомами викладання, але й задля перевірки чи не допускає викладач відхилень від партійних позицій. Саме суспільні дисципліни формували не просто 
судноводія, але громадянина з комуністичними переконаннями. Наприклад, викладача історії народів СРСР Херсонського морехідного училища Міністерства морського флоту (ММФ) у 1952 р. звільнили з посади, визнавши недостатньо кваліфікованим, оскільки, викладаючи дисципліну, він «допускав відрив історії від сучасності, не проводив чіткого пояснення історичних фактів 3 партійних позицій» [4, с. 25]. Викладачу літератури Одеського морехідного училища під час взаємовідвідування занять зробили зауваження з приводу розбору релігійності одного з персонажів п'єси Островського «Гроза» без приділення уваги антирелігійній пропаганді, проте, відзначили позитивним наведення прикладу про В. Леніна, який любив цитувати Островського та розповідати про світове значення драматурга [2, с. 41].

Попри значну увагу до суспільних дисциплін, які репрезентують соціокультурну складову професійної освіти майбутніх судноводіїв, у даний період існували недоліки, пов'язані з їхнім викладанням, що засвідчено в архівних джерелах: книжне засвоєння студентами марксизму-ленінізму, елементи школярства, догматизм, начотництво. Програми з суспільних наук в основному орієнтували на пасивні форми роботи зі студентами. Більшість учбового часу відводилась на лекції, які повторювали літературу 3 цих питань, доступну для самостійного вивчення студентами. Наприклад, з курсу політичної економії у технічних вузах зі 150 годин - 84 години виділялось на читання лекцій, з діалектичного та історичного матеріалізму з 90 годин - лекційних 50. Теми лекцій дублювали розділи підручників та учбових посібників, більшість семінарських занять повторювали зміст лекцій, майже не поглиблюючи та не розвиваючи їх [12, c. 155].

Згідно з постановою ЦК КПРС «Про викладання у вищих навчальних закладах політичної економії, діалектичного та історичного матеріалізму та історії КПРС» від 18.06.1956 р. у всіх вузах країни з 1956-1957 н.р. вводились перераховані дисципліни у вигляді самостійних курсів. Подальші реформи спрямовувались на зменшення догматизму у викладанні матеріалу, що сприяло підвищенню якості викладання [7].

Викладачі середніх спеціальних морських навчальних закладів об'єднувались у предметні та циклові комісії з метою вдосконалення навчальної та виховної роботи 3 одного або декількох споріднених предметів. 
Проведений аналіз протоколів засідань, планів роботи циклових комісій з історії, російської мови та літератури; пізніше циклових комісій з історії, суспільствознавства та літератури; циклових комісій з англійської мови дає підстави стверджувати, що головними заходами, передбаченими на навчальний рік для всіх циклових комісій були: 1) слідкувати за новинками політичної та спеціальної літератури 3 предметів; 2) готувати та проводити з курсантами доповіді на теми про авторитет радянської літератури, культури, цінностей тощо; 3) регулярно читати політичні та методичні журнали; проводити з курсантами політінформації (часто їх влаштовували самі курсанти під керівництвом викладача); 5) вивчати твори класиків марксизму-ленінізму; 6) регулярно підвищувати ідейно-теоретичний рівень та ділову кваліфікацію викладача $[10 ; 13]$.

Серед головних завдань, на здійснення яких спрямовувалась навчальнометодична робота були: 1) прищеплення курсантам марксистсько-ленінського світогляду, виховання патріотизму, любові до батьківщини, чесності, мужності, стійкості у боротьбі з труднощами та безмежної відданості справі Леніна-Сталіна; 2) виховання у курсантів любові до власної спеціальності та відмінного оволодіння знаннями зі спеціальності; 3) виховання у курсантів воїнської та трудової дисципліни; 4) неухильне підвищення якості викладання (викладання на високому ідейнотеоретичному рівні у розвитку науки і техніки); 5) підготовка висококваліфікованих фізично здорових, морально-стійких кадрів для морського та воєнно-морського флоту $[4$, c. $40 ; 5$, c. 2$]$.

Висновки. Розвиток соціокультурної складової професійної освіти майбутніх судноводіїв у 50-ті pp. XX ст. позначений впливом партійних органів та характеризується тенденціями посилення радянського патріотизму i формування суспільно-корисних громадян. Середні спеціальні та вищі навчальні заклади 3 підготовки морських фахівців підпорядковувались нормативно-правовим актам освітньої галузі, спрямованим на покращення викладання суспільних дисциплін та ідеологічну підготовку молоді. Поступово збільшувалась частка заідеологізованих предметів, посиленої практики набувало проведення з курсантами політінформацій, бесід про авторитет радянської літератури, культури, цінностей тощо, саме дисципліни соціокультурного спрямування якнайширше висвітлювали дану тематику. 


\section{References}

1. Verbii I. V. Vyznachennia poniattia «sotsiokulturna skladova osvity maibutnikh sudnovodiiv» [Definition of the concept "socio-cultural component of education of future navigators"]. Pedahohichnyi almanakh: zbirnyk naukovykh prats. Kherson, 2018. Issue 38. P. 89-95.

2. Hodovoi otchet o rabote OMU za 1951-1952 uch. hod [Annual report on the work of OMC for 1951-1952 academic year]. Derzhavnyi arkhiv Odeskoi oblasti. F. R-2018. Op. 4. Spr. 54. 96 ark.

3. KPSS $v$ rezoliutsyiakh y reshenyiakh siezdov, konferentsyi y plenumov TsK (1898-1988): $v 16 t$. [CPSU in resolutions and decisions of congresses, conferences and plenums of the Central Committee (1898-1988): in 16 v.]. / pod. obshch. red. A. H. Ehorova, K.M. Boholiubova. 9-e izd., dop. y yspr. Moskva: In-t marksyzma-leninizma pri TsK KPSS, 1985. Vol. 8: 1946-1955. 584 p.

4. Otchet za 1951-1952 uchebnyi hod Khersonskoho morekhodnoho uchylyshcha Mynysterstva Morskoho flota [Report for the 1951-1952 academic year of Kherson Maritime College of the Ministry of the Navy.]. Derzharkhiv Khersonskoi obl. (Derzhavnyi arkhiv Khersonskoi oblasti). F. R-472. Op. 4. Spr. 28. 255 ark.

5. Otchet o rabote uchylyshcha za 1953-1954 uchebnyi hod [Annual report on the work of college for 1953-1954 academic year]. Derzharkhiv Khersonskoi obl. (Derzhavnyi arkhiv Khersonskoi oblasti). F. R-472. Op. 4. Spr. 40.84 ark.

6. Penza I. V. Katehoriino-poniatiinyi aparat problemy rozvytku sotsiokulturnoi skladovoi profesiinoi osvity maibutnikh sudnovodiiv [Categorical-conceptual apparatus of the problem of development of socio-cultural component of professional education of future navigators] // Aktualni problemy suchasnoi pedahohichnoi nauky: materialy vseukrainskoi naukovo-praktychnoi konferentsii (Drohobych, 9-10 kvitnia 2020 r.). Drohobych: Redaktsiino-vydavnychyi viddil Drohobytskoho ped. un-tu im. I. Franka, 2020. Pp. 160-163.

7. Petrushenko A. D, Rybakova V. M. Reformyrovanye systemy obrazovanyia $v$ SSSR $v$ peryod «ottepely» (1953-1964 hh.) [Reforming the education system in the USSR during the "thaw" (1953-1964)]. Trudy molodykh uchenykh: sbornyk materyalov y dokladov. Moskva, 2010. Pp. 93-97.

8. Petko L. V. Yednist navchannia $i$ vykhovannia $u$ formuvanni profesiino oriientovanoho inshomovnoho navchalnoho seredovyshcha $v$ umovakh universytetu [Unity of teaching and upbringing in the formation of professionally oriented foreign language learning environment at conditions of university] : monohrafiia. Kyiv : Talkom, 2017. 337 p. ; bibliohr.

9. Pet'ko L.V. Imperativ globalizatsiynyh perspektyv - formuvannya profesiyno spryamovanogo inshomovnogo navchalnogo seredovischa $v$ umovah universitetu [The imperative of globalization perspectives - the forming of the professionally directed foreign language educational environment in the conditions of university]. Pedagogika vyshhoi' ta seredn'oi' shkoly: zb.nauk.prac'. Issue 41. Kryvyj Rig : Drukarnja Romana Kozlova, 2014. Pp. 254-261.

10. Plan raboty, protokoly zasedanyi y otchet tsyklovoi metodycheskoi komyssyy anhlyiskoho yazyka [Work plan, minutes of meetings and report of the cycle methodical 
commission of the English language]. Derzharkhiv Khersonskoi obl. F. R-472. Op. 4. Spr. 126. 112 ark.

11. Postanovlenyia plenuma $T s K K P / b / U$ (oryhynaly) [Resolutions of the plenum of the Central Committee of the CP / b / U (originals)]. Tsentralnyi derzhavnyi arkhiv hromadskykh obiednan. F. 1. Op. 1. Spr. 978.92 ark.

12. Protokoly No 1-4, stenohramy ta inshi dokumenty zasidan kolehii MVO URSR [Protocols No 1-4, transcripts and other documents of meetings of the board of MVO of the USSR]. Tsentralnyi derzhavnyi arkhiv vyshchykh orhaniv vlady ta upravlinnia Ukrainy. F. R4621. Op. 1. Spr. 140. 228 ark.

13. Protokoly zasedanyi, plany raboty tsyklovoi metodycheskoi komyssyy ystoryy, russkoho yazyka y lyteratury [Minutes of meetings, work plans of the cycle methodical commission of history, Russian language and literature]. Derzharkhiv Khersonskoi obl. F. R472. Op. 4. Spr. 123. 43 ark.

14. Slyusarenko N. V., Verbyi Y. V. Korreliatsyia poniatyi «sotsyokulturnaia sostavliaiushchaia obrazovanyia»y «sotsyokulturnaia kompetentnost» [Correlation of the concepts "socio-cultural component of education" and "socio-cultural competence"]. Doklady Kazakhskoi akadem. obrazovanyia. 2018. No 3. Pp. 124-131.

15. Slyusarenko N., Lypshyts L. Osobennosty sotsyalno-humanytarnoi podhotovky budushchykh sudovodytelei kak faktora formyrovanyia ykh sotsyokulturnoi kompetentnosty. [Features of social and humanitarian training of future navigators as a factor in the formation of their socio-cultural competence]. Obrazovanye v 21-om veke. Erevan: EHU Press, 2019. No 2(2). Pp. 38-45.

16. Slyusarenko N. V., Lypshyts L. V. Strukturnye komponenty modely formyrovanyia sotsyokulturnoi kompetentnosty budushchykh sudovodytelei mezhdunarodnykh reisov [Structural components of the formation model of socio-cultural competence of future navigators in international voyages]. Doklady Kazakhskoi akademyy obrazovanyia. 2017. No 1. Pp. 21-30.

17. Turchynova H. V. Psykholinhvistychni peredumovy ovolodinnia inozemnoiu movoiu dlia spetsialnykh tsilei [Psycholinguistic prerequisites for mastering a foreign language for special purposes]. Naukovi zapysky. Kyiv : Vyd-vo NPU imeni M. P. Drahomanova, 2011. Issue LXXXXVIII (98). Pp. 201-207.

18. Pet'ko Lyudmila. About socio-culturological content in teaching subjects // Development strategy of science and education: Collection of scientific articles. - Fidelite editions, Namur, Belgique, 2017. P. 316-319.

19. Slyusarenko N., Soter M. The Webquest as a Means of Improving the Efficiency of Students' Foreign Language Training of Ukrainian Technical Institutions of Higher Education (Beginning of the $21^{\text {st }}$ Century). Intellectual Archive. Toronto: Shiny Word.Corp. (Canada). 2020. Vol. 9 (April/June). No. 2. Pp. 94-104.

DOI: https://doi.org/10.32370/IA_2020_06_13

Translation of the Title, Abstract and References to the Author's Language 


\section{УДК 378.1}

Пенза Ірина. Розвиток соціокультурної складової професійної освіти майбутніх судноводіїв у 50-ті роки $X X$ століття.

Стаття присвячена розвитку соціокультурної складової професійної освіти майбутніх судноводіїв у 50-ті роки XX століття. Розглянуто постанови ЦК ВКП (б) та ЦК КПРС, які впливали на викладання дисциплін, що представляють соціокультурну складову. Визначено, що у даний період посилювалось керівництво партійних органів науковими закладами республіки, для вивчення у вищих та середніх спеціальних навчальних закладах обов'язковими були теми про дружбу народів, радянський патріотизм, історію розвитку суспільно-політичної, філософської та економічної думки в Україні, вплив російської суспільно-політичної думки та культури на розвиток української культури. Зроблено висновок, що оскільки навчальні заклади з підготовки майбутніх судноводіїв підпорядковувались нормативно-правовим актам освітньої галузі, розвиток соціокультурної складової освіти позначений надмірною політизацією та заідеологізованістю.

Ключові слова: розвиток, соціокультурна складова освіти, майбутні судноводії, суспільні дисципліни, постанова, навчальні заклади.

\section{Література}

1. Вербій І. В. Визначення поняття «соціокультурна складова освіти майбутніх судноводіїв» Педагогічний альманах: збірник наукових праць. 2018. Вип. 38. С. 89-95.

2. Годовой отчет о работе ОМУ за 1951-1952 уч. год. Державний архів Одеської області. Ф. Р-2018. Оп. 4. Спр. 54. 96 арк.

3. КПСС в резолюциях и решениях съездов, конференций и пленумов ЦК (1898-1988): в 16 т. / под. общ. ред. А. Г. Егорова, К. М. Боголюбова. 9-е изд., доп. и испр. Москва : Ин-т марксизма-ленинизма при ЦК КПСС, 1985. Том 8: 1946-1955. $584 \mathrm{c}$.

4. Отчет за 1951/52 уч. год Херсонского мореходного училища Министерства Морского флота. Держархів Херсонської обл. (Держсавний архів Херсонської області). Ф. Р-472. Оп. 4. Спр. 28. 255 арк.

5. Отчет о работе училища за 1953/54 уч. год. Держархів Херсонської обл. (Державний архів Херсонської області). Ф. Р-472. Оп. 4. Спр. 40. 84 арк.

6. Пенза I. В. Категорійно-понятійний апарат проблеми розвитку соціокультурної складової професійної освіти майбутніх судноводіїв. Актуальні проблеми сучасної педагогічної науки: матеріали всеукраїнської науково-практичної конференції (Дрогобич, 9-10 квітня 2020 р.). Дрогобич: Редакційно-вид. відділ Дрогобицького пед. ун-ту ім. І. Франка, 2020. С. 160-163.

7. Петрушенко А. Д, Рыбакова В. М. Реформирование системы образования в СССР в период «оттепели» (1953-1964 гг.). Труды молодых ученых: сборник материалов и докладов. Москва, 2010. С. 93-97.

8. Петько Л. В. Єдність навчання $\mathrm{i}$ виховання у формуванні професійно орієнтованого іншомовного навчального середовища в умовах університету : монографія. Київ : Талком, 2017. 337 с. 
9. Петько Л. В. Імператив глобалізаційних перспектив - формування професійно спрямованого іншомовного навчального середовища в умовах університету. Педагогіка вищої та середньої школи: зб.наук.праць ; за ред. З.П.Бакум. Криворізький педагогічний інститут ДВНЗ «Криворізький національний університет». Вип. 41. Кривий Ріг : Друкарня Романа Козлова, 2014. С. 254-261.

10. План работы, протоколы заседаний и отчет цикловой методической комиссии английского языка. Держархів Херсонської обл. Ф. Р-472. Оп. 4. Спр. 126. 112 арк.

11. Постановления пленума ЦК КП/б/У (оригиналы). Центральний державний архів громадських об'єднань. Ф. 1. ОП. 1. Спр. 978.92 арк.

12. Протоколи №№1-4, стенограми та інші документи засідань колегії МВО УРСР. Центральний державний архів вищих органів влади та управління Украӥни. Ф. Р4621. Оп. 1. Спр. 140. 228 арк.

13. Протоколы заседаний, планы работы цикловой методической комиссии истории, русского языка и литературы. Держархів Херсонської обл. Ф. Р-472. Оп. 4. Спр. 123. 43 арк.,

14. Слюсаренко Н. В., Вербий И. В. Корреляция понятий «социокультурная составляющая образования» и «социокультурная компетентность». Доклады Казахской академии образования. 2018. № 3. С. 124-131.

15. Слюсаренко Н., Липшиц Л. Особенности социально-гуманитарной подготовки будущих судоводителей как фактора формирования их социокультурной компетентности. Образование в 21-ом веке: международный научно-методический рецензированный журнал. Ереван: ЕГУ Пресс, 2019. № 2(2). С. 38-45.

16. Слюсаренко Н. В., Липшиц Л. В. Структурные компоненты модели формирования социокультурной компетентности будущих судоводителей международных рейсов. Доклады Казахской академии образования. № 1. 2017. C. $21-30$.

17. Турчинова Г. В. Психолінгвістичні передумови оволодіння іноземною мовою для спеціальних цілей. Наукові записки : [збірник наукових статей] / М-во освіти і науки, молоді та спорту України, Нац. пед. ун-т імені М. П. Драгоманова ; укл. Л. Л. Макаренко. - Київ : Вид-во НПУ імені М. П. Драгоманова, 2011. Випуск LXXXXVIII (98). C. 201-207.

18. Pet'ko Lyudmila. About socio-culturological content in teaching subjects // Development strategy of science and education: Collection of scientific articles. - Fidelite editions, Namur, Belgique, 2017. P. 316-319.

19. Slyusarenko N., Soter M. The Webquest as a Means of Improving the Efficiency of Students' Foreign Language Training of Ukrainian Technical Institutions of Higher Education (Beginning of the $21^{\text {st }}$ Century). Intellectual Archive. Toronto: Shiny Word.Corp. (Canada). 2020. Vol. 9 (April/June). No. 2. Pp. 94-104.

DOI: https://doi.org/10.32370/IA_2020_06_13 